\title{
FIRM SIZE, MARKET LIBERALIZATION AND GROWTH
}

\author{
Petar Stankov
}

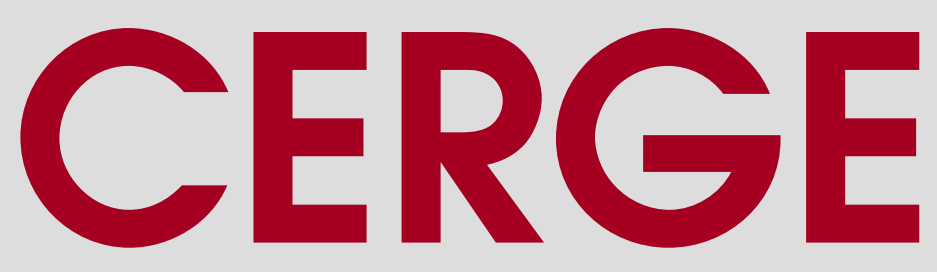

Charles University

CenterforEconomic Research and Graduate Education

Academy of Sciences of the Czech Republic

Ec onomic Institute 


\title{
Working Paper Series 485 (ISSN 1211-3298)
}

\section{Firm Size, Market Liberalization and Growth}

\author{
Petar Stankov
}

CERGE-EI

Prague, April 2013 
ISBN 978-80-7343-289-8 (Univerzita Karlova. Centrum pro ekonomický výzkum a doktorské studium)

ISBN 978-80-7344-281-1 (Národohospodářský ústav AV ČR, v.v.i.) 


\title{
Firm Size, Market Liberalization and Growth
}

\author{
Petar Stankova,b \\ ${ }^{\mathrm{a}}$ CERGE-EI, ${ }^{*}$ Politickych veznu 7, 11121 Prague, Czech Republic \\ ${ }^{\mathrm{b}}$ Department of Economics, UNWE, J.K. Studentski Grad, 1700 Sofia, Bulgaria
}

\begin{abstract}
Economies have markedly different firm size distributions. At the same time, firms of different size grow differently after identical financial- and product-market liberalization reforms. Thus, identical reforms can produce different growth outcomes across countries. This result is reached after exploring firm-level data on sales and sales per worker across 135 developing and post-transition economies. It helps explain the remarkable variation in the vast development literature studying the effects of various market-oriented reforms across countries and over time.
\end{abstract}

\begin{abstract}
Abstrakt
Mezi ekonomikami existují výrazné rozdíly v distribuci velikosti firem. Zároveň, různě velké firmy rostou různou rychlostí po identických liberalizačních reformách finančních trhů a trhů výrobků. Z tohoto důvodu identické reformy můžou vést $\mathrm{k}$ různému ekonomickému rozvoji různých ekonomik. Toto je potvrzeno pomocí analýzy firemních dat o tržbách a tržbách na zaměstnance ze 135 rozvojových zemí a zemí po ekonomické transformaci. Tento výsledek pomáhá objasnit pozoruhodnou variaci v obsáhlé rozvojové literatuře, která se zabývá efektem různých tržně-orientovaných reforem v různých zemích a časových horizontech.
\end{abstract}

JEL Codes: D22, L11, L25, L53, 012, 043

Keywords: Financial reforms, economic growth, firm size distributions, reform outcome divergence

${ }^{*}$ CERGE-EI, a joint workplace of Charles University in Prague and the Economics Institute of the Academy of Sciences of the Czech Republic. Email: pstankov@cerge-ei.cz 


\section{Introduction}

Suppose an identical market-oriented reform is adopted simultaneously across a number of countries. Will the reformers be affected identically? This paper argues they will not, and looks for the reasons behind an eventual outcome divergence. The explanation offered here, and the main hypothesis of this work, is that economic liberalization - i.e., the state's withdrawal from its legal powers to direct pricing, entry and exit on a given market (Winston, 1993) - affects firms of different size differently. Then, if two countries go through identical reforms but their firm size distributions are ex-ante different, the two economies will react differently to the reform. Naturally, the argument extends to more than two economies and to more than one liberalization reform. It also produces a variety of reform outcomes across countries and possibly over time.

Previous work has shown that, indeed, different economies may benefit differently from an identical reform. For example, Aghion, Alesina, and Trebbi (2007) use industry-level data to demonstrate that entry liberalization affects different industries differently. More specifically, industries closer to the technology frontier would be affected more by entry liberalization and would innovate more than backward industries in order to prevent entry. Thus, countries closer to the world technology frontier benefit more from a liberalization reform because they have a higher share of innovating industries. As a result, those countries also grow faster after a reform.

By using firm-level data and linking it with country-level reforms, I find that although firms closer to the technology frontier do innovate more, they do not do so as a result of market-oriented reforms. This finding motivates me to argue that the literature has largely ignored one of the important and at the same time intuitive determinants of reform outcome divergence across 
countries. In this work, I hypothesize that it is the firm size, among other factors, which drives the different impact of identical liberalization reforms on firm growth across countries. I test this hypothesis by using data on sales and sales per worker of more than 110,000 firm-level observations in 135 developing and post-transition economies. Firm sales and sales per worker are conditioned on country data on credit market liberalization reforms, on an overall economic liberalization reform, as well as on other aggregate and firm-level observables.

The advantage of having firm-level data in this study is that reform impact is studied at a level at which it allegedly matters most for growth, and where the growth decisions are actually taken: the firm. This work finds sufficient evidence to conclude that the cross-country variation in firm size distributions before the reform takes place is one of the drivers behind growth divergence across countries after the reforms.

The next sections illustrate how the literature around this problem evolved, including why it could be assumed that the firm-size distribution (FSD) is exogenous to policy changes in the short run.

\section{Literature review}

\subsection{Overall impact of market liberalization on growth}

Since George Stigler and his coworkers pioneered the rigorous study on the effects of various regulations in the $1960 \mathrm{~s},{ }^{1}$ a vast literature emerged on how product-, labor- and capital-market liberalization affect entry, exit, employment, investment and productivity, among other determinants of economic growth. The literature moved from studying specific regulations (e.g. price or quantity) within a specific industry (e.g. trucking or airlines) in the 1980s

\footnotetext{
${ }^{1}$ See Stigler (1988, p.116-118) for a brief history of that work.
} 
to broader studies of how regulation affects growth, growth factors or living standards across countries. Examples of the latter include Djankov, La Porta, Lopez-de-Silanes, and Shleifer (2002) and Botero, Djankov, La Porta, Lopezde-Silanes, and Shleifer (2004) on regulations of entry and labor, respectively. Along similar lines, Bertrand and Kramarz (2002) investigate the significant negative effects of hampering entry liberalization on job creation, while Alesina, Ardagna, Nicoletti, and Schiantarelli (2005) establish a positive relationship between product market liberalization and investment in seven big OECD industries.

The work by Alesina et al. (2005) was extended by using firm-level data from both developed and developing economies, which include both small and large firms. In three studies Ardagna and Lusardi (2008, 2009a, 2009b) find that more cumbersome entry and labor regulations discourage firm entry, and that the effects are unequal across a number of individual firm characteristics. Klapper, Laeven, and Rajan (2006) also show that entry rates by firms are significantly affected by entry regulations, and further conclude that countries with stricter entry regulations induce larger size of entering firms but also slower firm growth afterwards. In effect, aggregate growth slows down because of slower firm growth.

More recently, empirical works rely on firm-level data, in which micro and small firms represent the sample majority, thereby making the results more credible. Commander and Svejnar (2011) link firm performance from the Business Environment and Enterprise Performance (BEEPS) data with a wide range of institutional constraints on firm growth. Contrary to previous empirical findings, they do not support the hypothesis that institutional constraints matter for firm performance in Central and Eastern Europe (CEE) and the former Soviet Union, and find that country fixed effects are per- 
haps the main determinant of firm performance in the region. Commander and Nikoloski (2010) use more countries than Commander and Svejnar and also find that the relationship between institutions, as measured in the Doing Business Database, and firm performance, is not robust across countries. Specifically, firms in countries belonging to different income groups are affected differently by reforms, with the reforms having the expected positive sign only in high- and upper-middle income groups.

Although Commander and Nikoloski (2010) control for firm size, they do not use firm size as a factor which, if combined with the effect of the reform, could determine differences in reform outcomes across countries. There is an emerging body of empirical evidence of differences in the responses of small and large firms to various types of liberalization reforms.

\subsection{The effect of economic liberalization across firms of different size}

Studies in various lines of empirical literature on liberalization - especially trade and financial liberalization - document a differential effect of reforms on firms of different size. The differential impact of the trade liberalization between Turkey and the EU on small and large firms is studied by Erzan and Filiztekin (1997). Their conclusion is that small firms' value-added growth decreased after the introduction of the Customs Union (CU) with the European Union, while the impact on large firms was mostly insignificant.

The reason for different reform outcomes for small and large firms is often described in the IO literature as "compliance asymmetries." In particular, Millimet (2003) argues that smaller firms are disadvantaged in their resources to investigate and challenge legislative changes. Therefore, economic liberalization may have disproportionate effects on firms of different size. Moreover, 
large firms spread the fixed compliance costs attributed to a given regulation over a larger output which gives them a cost advantage.

The finance literature also analyses the difference between the effects of financial regulation on the costs of small and large firms. For example, Franks, Schaefer, and Staunton (1997) find that the ratio between the direct and indirect compliance costs of financial regulations tends to decrease with size. Consequently, larger firms are less affected by financial regulations as well. Contrary to this conclusion, Bena and Jurajda (2007) find little evidence of a differential effect of financial development across firm size, conditional on the firms reaching certain minimum size (in their data it is 100 employees and 20 million Euro of total assets).

Aghion et al. (2007) provide a strong intuition why identical reforms may exert a different effect across different economies. The core of their argument is that firms closer to the technology frontier would benefit from easing industry entry more than the backward firms because they innovate more to deter entry, and find industry-level evidence for this differential impact. In a supporting study, Bourlès, Cette, Lopez, Mairesse, and Nicoletti (2010) find that industries closer to the technology frontier would benefit more from liberalizing product market regulations, thus extending the argumentation in Aghion et al. (2007).

However, micro-level evidence presented further in this work suggests that it is not necessarily the position on the technology ladder that determines the different reaction of firms to liberalization reform. Rather, it is the size of the firm. Therefore, it can be argued that if the firm-size distributions across two economies are different, then an identical reform may have different growth impacts because firms of different size react differently to liberalization. The next section illustrates the observed differences in the firm-size distributions 
(FSDs) across countries and argues why those differences matter for delivering different reform outcomes across countries.

\section{$3 \quad$ Firm-size distributions across countries}

Establishing any evidence of a differential effect of an identical reform across countries hinges on several important questions. First, are there significant differences in the firm-size distributions (FSDs) across countries? If the FSDs are the same, then the reform outcomes across countries would hardly be significantly different, even if small and large firms are found to grow differently after the reform. Second, do reforms influence those distributions? If FSDs are influenced by the reforms over short periods of time, then the FSDs themselves would be endogenous to the liberalization reforms. Therefore, it is important to know whether one can take the FSDs as exogenous at least in a cross-sectional setting. Third, are the cross-country growth differences affected by the differences in the FSDs? If they are, then a reform could not only have a different effect on firms of different size but it could also bring aggregate reform implications across countries. This part of the paper addresses each of these questions.

Over recent decades there have been substantial efforts to explain the statistical regularities behind FSDs both within and across countries, and over time. Gabaix (2009) reviews the evidence that FSDs in developed countries are found to have a Zipf distribution, at least in their upper tails. ${ }^{2}$ However, in some developed countries such as Japan (Kaizoji, Iyetomi, \& Ikeda, 2005), and most notably in the developing world, this regularity in FSDs is harder

\footnotetext{
${ }^{2}$ Following Gabaix (2009), the Zipf distribution in firm size essentially means that the probability of a firm size $S$ being greater than $x$ is inversely proportional to $x$. More formally, $P(S>x) \simeq k x^{-\alpha}$, and in the particular case of Zipf distribution, $\alpha \simeq 1$.
} 


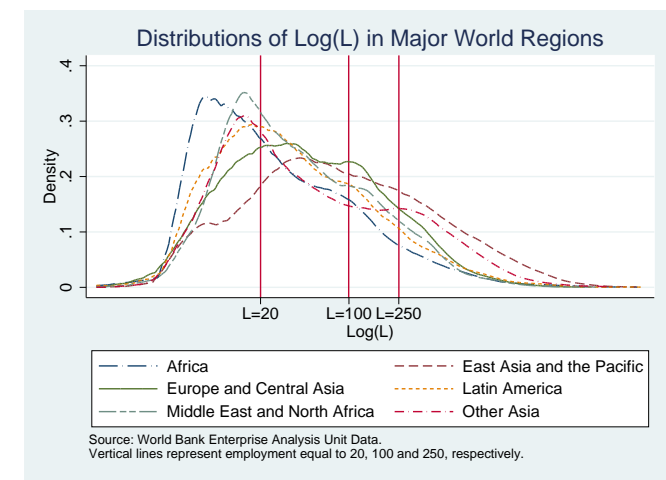

(a) $\log (\mathrm{L})$

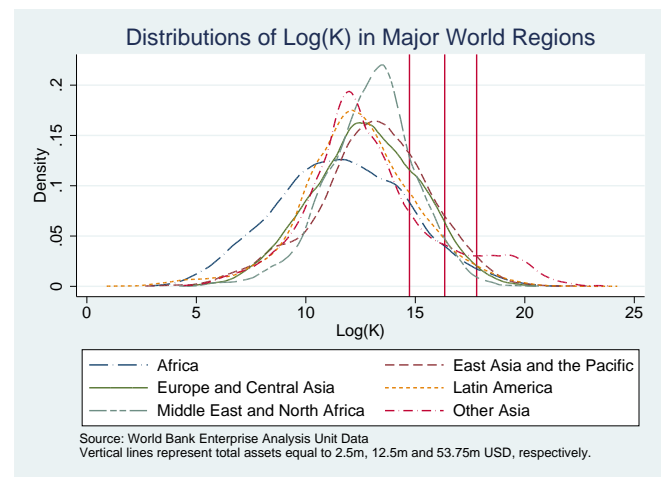

(b) $\log (\mathrm{K})$

Figure 1: Firm-Size Distributions of Employment and Assets

to observe, as the data presented here and additional evidence suggests. ${ }^{3}$ In addition, looking at Figure 3, it is obvious that there are marked differences in FSDs across major regions of the world, especially in the small-firm segments of the distributions. ${ }^{4}$ Those differences may be explained by several theoretical and empirical arguments.

First, many young firms operate in the small-firm segment. Those firms' growth is more volatile (Alexander, 1949; Samuels \& Smyth, 1968). They also grow faster but are also more likely to fail (Dunne, Roberts, \& Samuelson, 1989; Jovanovic, 1982; Mansfield, 1962; Mata, 1994). The snapshot of FSDs in Figure 3 captures marked differences in FSDs across major world regions exactly in the small firms segment [below 20 employees in Figure 1(a) and below USD 2.5m in assets in Figure 1(b)].

Second, trade theory produces a well-known proposition that different countries specialize in different industries. ${ }^{5}$ If there is a different evolution of FSDs across industries, then the within-country industry specialization

\footnotetext{
${ }^{3}$ For some differences in the FSDs between the developed and the developing world, see Alfaro, Charlton, and Kanczuk (2008).

${ }^{4}$ The first and the last percentiles of each tail are removed.

${ }^{5}$ See Heckscher-Ohlin and Rybczynski theorems.
} 
would give rise to divergent evolutions of FSDs across countries depending on their industrial structure.

Third, significant differences in FSDs across industries within a period (Rossi-Hansberg \& Wright, 2007) and different evolutions of FSDs across industries have been documented (Lotti \& Santarelli, 2004). Lotti and Santarelli (2004) study FSDs of new entrants in several industries and find they vary across their minimum-efficient scale and technological requirements. Technology is also found to be an important factor generating differences in FSDs across industries by Marsili (2005). These facts might explain the differences in FSDs at a point in time across countries, at least in their lower tails, as observed in Figure 3.

However, despite the marked cross-country differences in FSDs, and despite the documented underlying evolutionary process towards an equilibrium FSD within an industry (Hashemi, 2000, 2003), the within-country distributions are relatively stable, as found by Cabral and Mata (2003) and Henly and Sánchez (2009). Cabral and Mata (2003) also note that the FSD of a given cohort of firms changes slowly over time, while Henly and Sánchez (2009) add that the within-industry FSD changes over long periods of time and the within-country FSD stays unchanged. Doi and Cowling (1998) assert that in some countries (e.g., Japan) the share of output and employment across size classes is relatively constant over long periods of time, while in others (e.g., the UK) they change only slowly in favor of smaller firms. Axtell (2001) also concludes that FSDs are stable over time, at the same time being robust to the employed definition of firm size. Then, it can be assumed that FSDs are stable over relatively short periods of time, such as the one examined in this work, and are not affected by economic liberalization reforms in the short-run. 
Naturally, the above exogeneity assumption does not mean the withincountry and within-industry FSDs evolve independently as mere statistical regularities. ${ }^{6}$ After all, the differences in FSDs across countries came from an underlying difference in some fundamental factor. Lucas (1978) argues that FSD is underlined by a distribution of managerial talent. Thus, different countries end up having different FSDs depending on the international allocation of talent. At the same time, countries with lower quality of institutions and enforcement of property rights have a different allocation of talent into productive and rent-seeking occupations (Murphy, Shleifer, \& Vishny, 1991). Thus, it is tempting to explain the observed cross-country differences in FSDs with different underlying institutions and property rights systems.

Finally, there are emerging implications in the FSD literature that FSDs are correlated with cross-country income differences (Alfaro et al., 2008; Gabaix, 2009). This evidence contributes to the understanding that FSDs are an important determinant of cross-country differences in the growth effects of reforms.

In a nutshell, both the firm-level data used here and the size distribution literature point to significant differences in FSDs across countries. However, policies seem to do little to affect the evolution of FSDs over short periods of time within a country. Rather, FSDs are more likely to be driven by withinindustry product life cycles that have more to do with fundamentals such as preferences and factor endowments that affect industry specialization than with policies. Thus, it is legitimate to assume both the FSD within a country and the cross-country differences in FSDs as given, at least in a short panel, and especially in a cross-sectional data setting. However, the variation in the FSDs also affects the cross-country income differences. Then, it is very

\footnotetext{
${ }^{6}$ See Sutton $(1997,2007)$ for extensive discussions on FSD evolution.
} 
intuitive to hypothesize that an identical policy would have a different impact across countries based on its different effect on small and large firms. The empirical strategy to test this hypothesis is presented below.

\section{Empirical strategy}

\subsection{Confronting previous evidence}

Does economic liberalization influence firms of different size differently? I answer the question by considering the papers of Aghion et al. (2007) and Bourlès et al. (2010) as a starting point, and contribute to their works in several ways.

First, instead of using industry-level data, this work uses data with more than 110,000 firm-level observations, which spans a richer set of industries than the manufacturing data in Aghion et al. (2007) or in Bourlès et al. (2010). Besides manufacturing, the data set used here includes trade and other services, although it covers an admittedly lower number of countries than Aghion et al. (2007). The main advantage of the data set here is that it is able to reveal the actual decisions about innovation and growth at the firm level.

Second, I abstain from the definition of distance to the technological frontier in Aghion et al. (2007), which is more relevant at the industry level. Instead, I assume that firms have a good knowledge of the level of technology of their main competitors and of their own technology, and are able to compare them. This also assumes firms optimize based on the decisions of their nearest rival. If this reasoning is legitimate, three possibilities arise. Specifically, the firm can have a more advanced, a similar or an inferior technology to its closest rival. After classifying firms into these three broad categories, 
I estimate the following probit model:

$$
\begin{aligned}
P\left(y_{i}=1 \mid X_{i}\right)=\Phi\left(\beta_{0}\right. & +\beta_{1} A D V_{i}+\beta_{2} L A G_{i}+\beta_{4} A D V_{i} R_{j}+ \\
& \left.+\beta_{5} L A G_{i} R_{j}+\beta_{6} R_{j}+\mathbf{Z}_{i}^{\prime} \beta+f_{s}+\varepsilon_{i}\right),
\end{aligned}
$$

where $P\left(y_{i}=1 \mid X_{i}\right)$ is the probability of obtaining an ISO certification or of introducing a significant innovation in the firm's product line after economic liberalization. I further condition the firm's behavior on its relative position on the technology ladder: $A D V_{i}$ and $L A G_{i}$ are dummy variables indicating that a given firm has a superior (advanced, $A D V$ ) or inferior (lagging, $L A G$ ) technology compared to its main rivals; $R_{j}$ is a measure of how liberalized economic policies in country $j$ are, as measured by Worldwide Governance Indicators (WGI), by the Economic Freedom of the World (EFW) data, and by Heritage Foundation Data (HFD) $;^{7} A D V_{i} R_{j}$ and $L A G_{i} R_{j}$ are interactions between the technological standpoint of the firm and the liberalization variable to indicate the impact of liberalization on each step of the technology ladder relative to the firms that have about the same technology as their main competitor. Finally, $Z_{i}$ are other firm-level controls relevant for the innovation process such as the age of the firm, the experience of top management, sales in the previous period and the size class of the firm; $f_{s}$ are time-invariant sector effects; $\varepsilon_{i}$ is an error term that I assume to be uncorrelated with the explanatory variables and the $\Phi$ function has a normal distribution so that the parameter estimates in the above equation represent the direction of the impact of being a technologically advanced or inferior firm to the probability of innovation after the reform takes place.

By applying this methodology, this work answers the following question: Do technologically advanced firms innovate more after an economic liberalization reform? If indeed technologically advanced firms innovate more after

\footnotetext{
${ }^{7}$ See the data description for further details on these.
} 
a reform, then the theory by Aghion et al. (2007) would be supported by stronger firm-level evidence and by an empirical strategy that uses a direct comparison with the distance to the frontier from a firm's point of view. However, if advanced firms do not innovate more after a reform, then perhaps an alternative explanation would be needed on why different firms react differently to economic liberalization.

The firm-level evidence in favor of the above theory is mixed at best. It is presented in Table 1. Indeed, consistent with Aghion et al. (2007) and with Bourlès et al. (2010), technologically advanced firms innovate more, and backward firms innovate less than firms whose technology is about the same as the technology of their main competitors. However, the interaction between the level of technology and the reform is rarely significant, and if it is, its significance is not robust across different data sets measuring economic liberalization. Therefore, there is not enough support at the firm level for the evidence that the distance to the technological frontier drives the differential impact of economic reforms across countries, and perhaps a new explanation is in order. The new explanation is based on the hypothesis that small and large firms react differently to reforms. The methods to test this hypothesis are presented below.

\subsection{Estimation Strategy}

To test the hypothesis that firms of different size grow differently after economic liberalization, I estimate the following baseline model for the growth of firm $i$ in country $k$ at time $t$ :

$$
\begin{aligned}
\log Y_{i k t}= & \alpha_{0}+\alpha_{1} \log Y_{i k t-1}+\alpha_{2} \log K_{i k t}+\alpha_{3} \log L_{i k t}+ \\
& +\alpha_{4} C M R_{k t} S_{i k t}+\alpha_{5} R_{k t} S_{i k t}+\alpha_{6} R o L_{k t} S_{i k t}+ \\
& +\alpha_{7} T_{k t} S_{i k t}+\mathbf{Z}_{i k t}^{\prime} \alpha+f_{s t}+f_{k t}+\varepsilon_{i k t},
\end{aligned}
$$


where $\log Y_{i k t}$ stands for either sales, $\log S A L_{i k t}$, or the sales per worker, $\log S P W_{i k t}$, of firm $i$ in country $k$ in period $t$. In addition, $\log K_{i k t}$ and $\log L_{i k t}$ are the value of total assets and the labor costs, respectively, to estimate the impact of the main factors of production; ${ }^{8} C M R_{k t}, R_{k t}, R_{o} L_{k t}$ and $T_{k t}$ are the indices of credit market regulation, overall regulation, the rule of law, and international trade policies, respectively, for country $k$ in period $t$, taken from EFW indices $;{ }^{9} S_{i k t}$ is the size of the firm measured by either the log-number of employees or by the log-value of assets; $\mathbf{Z}_{i k t}^{\prime}$ is a vector of firm observables, including whether the firm has obtained an ISO certification, to capture some differences in the growth of firms with different levels of technology and more sophisticated management procedures, legal structure, age of the firm, and top manager experience.

Further, in order to capture common but temporary shocks to firm performance within an industry or a country, the model includes industry-specific and country-specific dummies for each of the available years in the sample. The interactions of the country dummies with the year dummies would also capture the overall reform processes happening in the country. That is why the model does not include liberalization indices as distinct explanatory variables - they are captured by the country-year dummies. Finally, $\varepsilon_{i k t}$ is the error term about which it is assumed, at least for now, to be distributed normally with a zero mean, and to satisfy classic linear regression assumptions.

As the reform indices vary only on the country level, firm-level variation is introduced by interacting the indices with the log-number of employees or

\footnotetext{
${ }^{8}$ When sales per worker is the main explained variable, $\log K_{i k t}$ and $\log L_{i k t}$ are transformed into capital per worker by dividing total assets by the number of employees.

${ }^{9} \mathrm{An}$ increase in the $C M R_{k t}$ index means financial liberalization, an increase in the $R_{k t}$ index means overall economic liberalization on labor, product, and credit markets, an increase in the $R o L_{k t}$ index means strengthening the rule of law, and an increase in $T_{k t}$ means trade liberalization.
} 
the log-value of assets of the firm. The interaction captures how differently small and large firms grow after financial liberalization, after overall economic liberalization reforms and after strengthening the rule of law. Thus, the interaction terms $C M R_{k t} S_{i k t}, R_{k t} S_{i k t}, R_{o} L_{k t} S_{i k t}$ and $T_{k t} S_{i k t}$ address the main question of this work, and $\alpha_{i}, i \in[4 ; 7]$ are the parameters of primary interest. If significant, they would demonstrate that firms of different sizes react differently to reforms. If the estimates are positive, then larger firms grow more than smaller firms after a given reform.

If we take the above equation as it is, we will have to assume, at least implicitly, that $K_{i k t}, L_{i k t}$ and the interaction terms are exogenous variables, which would be a strong assumption. For various reasons, all of the right hand-side variables in the above equation, except perhaps the size variable $S_{i k t}$, are endogenous. ${ }^{10}$ Therefore, both the identification and estimation of their parameters would require constructing a system of equations in which the endogenous variables in the baseline equation are being explained by some other factors outside of the baseline equation rather than being assumed as

\footnotetext{
${ }^{10}$ Naturally, the size $S_{i k t}$ is also endogenous. For the purposes of this work however, I take it as exogenous. The literature review demonstrates that the size distribution of firms is changing only slowly, and within a cross-section of data can be taken as independent from the policy changes. Then, if a given reform is enacted in some countries, it will be the initial size distribution variation that would determine the differences in the reaction of the economy, while the second-order effects of the liberalization reform, which run through the within-country changes of the size distribution, would appear only after a slow adjustment process. Then, this longer-term margin of adjustment is irrelevant in a cross-section of firms. Yet, I acknowledge the need to address the issue of endogenous firm-size adjustment by using a longer panel of firms.
} 
"weakly exogenous." This system is as follows:

$$
\begin{aligned}
& \log Y_{i k t}=\alpha_{0}+\alpha_{1} \log Y_{i k t-1}+\alpha_{2} \log K_{i k t}+\alpha_{3} \log L_{i k t}+ \\
& +\alpha_{4} C M R_{k t} S_{i k t}+\alpha_{5} R_{k t} S_{i k t}+\alpha_{6} R o L_{k t} S_{i k t}+ \\
& +\alpha_{7} T_{k t} S_{i k t}+\mathbf{Z}_{i k t}^{\prime} \alpha+f_{s t}+f_{k t}+\varepsilon_{1 i k t} \\
& \log Y_{i k t-1}=\rho_{0}+\rho_{1} \log Y_{i k t-2}+\rho_{2} \log K_{i k t-1}+\rho_{3} \log L_{i k t-1}+ \\
& +\rho_{4} C M R_{k t-1} S_{i k t-1}+\rho_{5} R_{k t-1} S_{i k t-1}+\rho_{6} R o L_{k t-1} S_{i k t-1}+ \\
& +\rho_{7} T_{k t-1} S_{i k t-1}+\mathbf{Z}_{i k t-1}^{\prime} \rho+f_{s t-1}+f_{k t-1}+\varepsilon_{2 i k t-1} \\
& \log K_{i k t}=\beta_{0}+\beta_{1} \log K_{i k t-1}+\beta_{2} \log r_{i k t}+\beta_{3} \log r_{i k t-1}+ \\
& +\beta_{4} \log Y_{i k t-1}+\beta_{5} R_{k t}+\beta_{6} R_{k t-1}+ \\
& +\beta_{7} R o L_{k t}+\beta_{8} R o L_{k t-1}+\varepsilon_{3 i k t} \\
& \log L_{i k t}=\gamma_{0}+\gamma_{1} \log L_{i k t-1}+\gamma_{2} \log w_{i k t}+\gamma_{3} \log w_{i k t-1}+ \\
& +\gamma_{4} \log Y_{i k t-1}+\gamma_{5} R_{k t}+\gamma_{6} R_{k t-1}+ \\
& +\gamma_{7} R o L_{k t}+\gamma_{8} R o L_{k t-1}+\varepsilon_{4 i k t} \\
& C M R_{k t} S_{i k t}=\delta_{0}+\delta_{1} C M R_{k t-1} S_{i k t-1}+\delta_{2} C M R_{k t-2} S_{i k t-2}+ \\
& +\delta_{3} C_{k t}+\varepsilon_{5 i k t} \\
& R_{k t} S_{i k t}=\eta_{0}+\eta_{1} R_{k t-1} S_{i k t-1}+\eta_{2} R_{k t-2} S_{i k t-2}+ \\
& +\eta_{3} C_{k t}+\varepsilon_{6 i k t} \\
& R_{o} L_{k t} S_{i k t}=\theta_{0}+\theta_{1} R o L_{k t-1} S_{i k t-1}+\theta_{2} R_{o} L_{k t-2} S_{i k t-2}+ \\
& +\theta_{3} C_{k t}+\varepsilon_{7 i k t} \\
& T_{k t} S_{i k t}=\mu_{0}+\mu_{1} T_{k t-1} S_{i k t-1}+\mu_{2} T_{k t-2} S_{i k t-2}+ \\
& +\mu_{3} C_{k t}+\varepsilon_{8 i k t},
\end{aligned}
$$

where the demand for production factors depends on present and lagged values of the exogenously determined factor prices, on the levels of the employed factors and on the output in previous periods, and on the policy determi- 
nants of the firm growth; the endogenous interaction terms depend on the past levels thereof, as well as on some country characteristic $C_{k t}$.

The reasons for building such a system are based on theory and intuition. First of all, basic economic intuition suggests that labor and capital demand would depend on prices. In addition, the input prices from the previous periods are included because the change in relative prices between labor and capital in the past may also influence the factor demand decisions in the current period. Further, the past values of the inputs are included as exogenous variables. It is not unreasonable to assume that if the firm overshot its labor demand in the last period, it may downsize in the current period, or if the managers of the firm had too few fixed assets in the last period, they may want to invest more this period. Also, if a firm had a good year, it may wish to expand by buying more capital and labor services the following year. This is the intuition to include also the previous values of sales or sales per worker in the factor demand decisions.

Finally, the decisions of the government on how much to liberalize depend on how much regulation there is in the first place. For example, if a country has liberalized extensively in the past periods and now the level of the overall regulatory burden is low, it may not need to reform much further. Also, the decision on how much to liberalize depends on some purely country-specific characteristic such as the political orientation of the incumbent government, the legal origin, the history of regional conflicts, or the resource endowments.

This system has its limitations as well. Its design is intended to capture a rather short-term effect of reforms on the growth of firms, or, alternatively, use a cross-country variation in reforms to answer an inherently dynamic question. Also, some reforms take much longer to affect hiring and investment decisions. Therefore, the system may miss any reform benefits for the firm 
that materialize over a longer term. A much longer panel of firms may address the longer-term effect of reforms more properly. In this case, it is data limitations affecting the decision to include only one lag of reforms: there is only one lag in the data spanning over 3 years for all firms. To capture any reform effect over the growth of firms within that period, I also estimate the above system in differences. The results are much stronger than estimating equation (2) in levels, and are discussed below. However, the cost of differencing is a massive loss of observations as fewer firms have lagged data on sales, assets, labor costs and number of workers.

Since the primary interest of this work is in the best possible estimation of equation (2), constructing the above system has the sole purpose of identifying $\alpha_{i}, i \in[4 ; 7]$, by finding possible instruments for the endogenous interaction terms. I estimate equation (2) by both OLS and 2SLS. In the 2SLS estimations, the exogenous variables in the rest of the system of equations are used as instruments, where the crucial role is played by the lagged values of the interaction term. The results from the baseline estimations of the above system are presented in Table 2 and Table 3. Further description of the tables is given in the results section, which follows the data description below.

\section{Data}

\subsection{Country-level data on reforms}

There is more than one source of country-level data on the variables used in equation (1). One of the widely used data sets is Worldwide Governance Indicators (WGI) for 1996-2010, constructed by Kaufmann, Kraay, and Mastruzzi (2010). The WGI dataset is constructed biannually for 1996-2002 and annually since 2003 in 6 areas: Voice and Accountability, Political Stability, 
Government Effectiveness, Regulatory Quality, Rule of Law and Control of Corruption. For the purposes of this work, the most relevant indicator of economic liberalization is the regulatory quality. The other data set used here is the Heritage Foundation Data (HFD) reported in Miller, Holmes, and Feulner (2013). It contains information on 10 broad reform areas across 181 countries. Among those reform areas are business freedom, investment freedom and labor freedom. I average those three freedoms to arrive at an index of overall liberalization that I further use in equation (1). The final data set I use in equation (1) and in equation (2) is the Economic Freedom of the World (EFW) data set.

The EFW data set, constructed by Gwartney, Hall, and Lawson (2012), was used as the main source of economic liberalization data. The EFW data contain information on both the overall country patterns of economic and property rights reforms but also on more specific patterns of credit market liberalization. The database contains annual indices of economic freedom in 5 areas: Size of Government, Legal Structure and Security of Property Rights, Access to Sound Money, Freedom to Trade Internationally and the Regulation of Credit, Labor, and Business. The last area in the database is the most relevant to the estimation of equation (2).

A positive feature of the EFW database is that it dates back well before the firm performance measures were obtained. Thus, I can construct instruments for both the overall and the specific market liberalization reforms, and for the rule of law. Those instruments are the indices of $C M R_{k t}, R_{k t}, R o L_{k t}$ and $T_{k t}$ in 1990 and in 1995, interacted with the size of the firm 3 years before the dependent variable was measured. Thus, endogeneity issues behind the interaction terms are allegedly mitigated. 


\subsection{Firm-level data}

The Enterprise Surveys (ES) firm-level data are collected by the Enterprise Analysis Unit (EAU) of the World Bank in various periods. The data set encompasses two broad periods: 2000-2005 and 2005-2011 in various countries. The first data set has more than 53,000 firm-level observations across more than 90 countries and the second one has more than 60,000 firm-level observations from more than 70 countries. Both data sets consist of a wide range of firm-level performance indicators. I stack them together so that I have a large cross-country data set spanning from 2000 to 2011 that I can further merge with the country-level data. Further, to reduce the number of empty industry-country cells, I drop any industry with less than 1000 observations, and any country with less than 100 observations.

The EAU data is perhaps the largest publicly available firm-level data set with relevance to the main hypothesis of this work. The results from testing it are presented below.

\section{Results}

By using industry-level data, Aghion et al. (2007) and later Bourlès et al. (2010) reveal some reasons why product market liberalization reforms might benefit advanced economies - or those economies with a higher share of advanced firms - more than economies with a higher share of backward firms. However, it was shown in Table 1 that firm-level evidence in support of their theory is weak. Therefore, a new hypothesis may explain why some economies benefit from liberalization reforms while others do not. I hypothesize that firms of different sizes react differently to deregulation. Thus, based on the notable differences in the size distribution of firms across countries, various 
economies would react differently to identical economic liberalization reforms.

To test the hypothesis, I use both OLS and 2SLS estimation of equation (2) in which the instruments for the endogenous variables are found in the rest of the system of equations. The results from these estimations are presented in Tables 2 and 3.

Tables 2 and 3 present the estimates of equation (2) by OLS and 2SLS. Within each table, two sets of estimations are conducted. The first set uses the number of employees as a proxy for firm size, whereas the second set of estimations uses the value of assets as a proxy for size. Within each set of estimations, four columns are presented. The first two columns present the estimates from equation (2) without the country-year effects and the second two columns present the estimates with the country-year effects. The reason to present both estimates was that time-varying and time-invariant country characteristics may turn out to be among the crucial determinants of the variation in the responses to reforms within each country, as already suggested by Commander and Svejnar (2011).

Tables 2 and 3 present evidence that liberalization reforms have different impacts on both sales and sales per worker of firms of different size. Table 2 demonstrates that credit market liberalization helps increase the sales per worker of larger firms more than the sales per worker of smaller firms. This result supports the different impact of financial regulations on small and large firms discussed by Franks et al. (1997). However, reforming product and labor markets affects smaller firms more. This is indicated by the negative sign on some of the estimates of $R^{*}$ Size. Strengthening the rule of law and trade liberalization also consistently helps improve the sales per worker of larger firms more. This is indicated by the parameter estimates on the interaction terms. Interestingly, this result does not hold across different 
measures of firm size, that is, when size is changed from number of employees to value of assets. Further, firm controls such as managerial experience and age of the firm do not appear to increase sales per worker, conditioned on the other controls. In addition, including both time-varying and time-invariant country effects in the estimated equation does not change the above result.

The above evidence suggests that larger firms benefit more from liberalizing credit markets, from strengthening the rule of law and from trade liberalization. At the same time, smaller firms benefit more from an overall reform that, apart from credit market liberalization, includes also labor- and product-market reforms.

There is a reason the results here are presented both with and without country fixed and time-varying effects. The reason is that the current literature seems to be still looking for conclusive evidence on the effects of various reforms on economic growth. Cross-country studies á la Djankov et al. (2002) and Botero et al. (2004) imply a positive impact of reforms. However, firm-level studies, e.g., Commander and Svejnar (2011), offer a more nuanced explanation of the growth impact of market-oriented reforms. The results here offer one of the possible explanations for the dissent analyzed well in Babecký and Campos (2011). The explanation is that firms of different size react to various reforms differently.

This result is much more clear in Table 4 and Table 5 . At the cost of a massive loss of observations, the estimations presented in those two tables gain insight into the growth of sales per worker and the growth of sales of firms of different size after various market-oriented reforms. The baseline equation is now estimated in differences. It tells a much more consistent story on the growth impact of various reforms across firms of different size. The main messages from Table 2 still stand. 
Without going into too much detail, bigger firms grow more than smaller firms after liberalizing credit markets, after improving the rule of law, and after trade liberalization. Unlike bigger firms, their smaller competitors benefit more from reforms in labor and product markets. The results are also robust to including country effects. With or without the country effects, the main result emerging from this analysis stands: The growth of firms of different size after market liberalization and property rights reforms is different. As a result, aggregate growth would also be affected by the within-country firm size distribution. Given the cross-country differences in the FSDs, it is intuitive why some countries benefit from market-oriented reforms, while others do not.

\section{Robustness checks and tests of instruments}

The results above would have causal interpretations only if the the error terms are uncorrelated with the explanatory variables, and if the instruments in the 2SLS estimations are valid and strong. To ensure that some unobserved firm-level effect is not driving the growth of the firms instead of the included explanatory variables, I employ two separate procedures. First, I store the residuals from each estimation and then regress the residuals on the observed firm-level explanatory variables. In all of those estimations of the error term, I get that the included explanatory variables have no effect on the unobservable firm-level effects. These conclusions are also supported by the residual plots against the included observables.

Second, I do a RESET test. The test rejects the hypothesis that there are no omitted variables in almost all models. These omitted variables could be either the power terms of the included explanatory variables or the firm fixed effects. Re-running the model and repeating the RESET test with 
the squared and higher-power terms still leads to a detection of omitted variables and the magnitude of the F-test does not go down, so the issue is not mitigated by the additional variables. Given the cross-sectional data, I have no way of controlling for the firm-specific fixed effects that I suspect are causing the specification issue.

Therefore, I presume that the unexplained parts of the variations in sales and sales per worker are driven by either the firm fixed effects or some random factor that is not causing an omitted variable bias (OVB). Moreover, the explanatory power of most models is large enough so I expect any OVB to be relatively small. Despite the small OVB, the core message still persists across all models.

However, the OVB is not the ultimate concern with these estimations. An additional issue arises with the Hansen J-test because it rejects the null of the validity of instruments in some of the estimations. This could be because the instruments are invalid or because of misspecification (Cameron \& Trivedi, 2005, p.277). In either way, the significant Hansen J-test calls for caution in interpreting the 2SLS estimates. The positive news about the instruments is that they are strong. This is indicated by the Angrist-Pischke first-stage F-test (APF) whose value is more than 10 in most cases and which is more conservative than the standard first-stage F-test.

Assuming the Hansen test does not undermine the main message of the paper, I perform several robustness checks. First, I add more instruments. I interact the values of the reform variables in the year 2000 with the size of the firm, and add the resulting variable to the list of instruments. Unlike 1995 and 1990 that were used to interact with size so far, the year 2000 is closer to the sample. I expect the inclusion of this instrument to add strength to the instruments. The results are presented in Table 6 and are robust to the 
ones presented in the main tables. I repeat the estimations with the higher number of instruments for sales and get similar conclusions.

Second, instead of using the EFW indices of reforms throughout this study, I plug the Abiad, Detragiache, and Tressel (2010) overall index of financial reforms for the CMR index in the main estimations. The goal is to see if the results are robust to a certain change in the data source of reforms. The results are presented in Table 7 and are roughly robust, with minor exceptions. An important exception is that firm sales per worker do not behave consistently better for larger firms after a CMR reform, or consistently better for smaller firms after an overall reform. The results are robust in another way though: firms of different size do not grow identically after various market liberalization reforms.

Third, because of multicollinearity concerns over the correlations of CMR and the overall index of regulation $\mathrm{R}$, I drop $\mathrm{R}$ from the main estimations, and stick with the CMR index offered by Abiad et al. (2010). The downside of this approach is that it introduces an OVB. Still, the results are roughly consistent. Overall, the robustness checks confirm the broad conclusions of this study.

\section{Conclusion}

By using firm-level data from a large number of developing and post-transition countries, it was shown that firms of different size grow differently after similar reforms. This could bring sizable aggregate implications for cross-country differences in the outcomes of many market-oriented reforms. Those differences could be determined, among other factors, by the notable variation in FSDs across countries.

In a policy context, the reform success depends on the share of firms with 
relative gains after the reform. If an economy has a larger share of smaller firms, then liberalizing product and labor markets would benefit this economy more than an economy populated by larger firms. Bigger firms seem to grow slower after those reforms. However, improving property rights, liberalizing trade and liberalizing the financial system would make an economy with a higher share of large firms grow faster than the economy populated by small firms.

The results here also partly explain why a given set of reforms might affect a number of countries differently, despite the similarity in those reforms. For example, a rich history of similar market-oriented reforms in Central and Eastern Europe has led to remarkably different reform outcomes. Offering an explanation for this and other growth divergences that occurred after a similar set of reforms could be considered the main contribution of this work to the development literature.

\section{$9 \quad$ Acknowledgements}

I thank Lubomír Lízal, Libor Dušek, Peter Katuščák, Evangelia Vourvachaki, Jan Švejnar, Jan Kmenta, Levent Çelik, Byeongju Jeong, Robin-Eliece Mercury and the participants at the $7^{\text {th }}$ Biennial Conference of the Czech Economic Society in Prague, November 2012, for their comments on earlier versions of this work. Randall K. Filer and Jan Hanousek helped me finalize the draft with additional referee comments. Richard Stock who is with the Academic Skills Center at CERGE-EI provided professional English editing support and Kamil Kovar translated the abstract. I also gratefully acknowledge financial assistance from the World Bank under the 2007 CERGE-EI/World Bank Student Grants to initiate this research. This project was also partially financed by the Grant Agency of the Czech Republic from its P402/11/P785 
grant and by a research center grant No. LC542 of the Ministry of Education of the Czech Republic. Most of the project was done at CERGE-EI with institutional support RVO 67985998 from the Academy of Sciences of the Czech Republic. All errors remain the sole responsibility of the author.

\section{References}

Abiad, A., Detragiache, E., \& Tressel, T. (2010). A new database of financial reforms. IMF Staff Papers, 57(2), 281-302. Retrieved from http:// dx.doi.org/10.1057/imfsp. 2009.23 doi: 10.1057/imfsp.2009.23

Aghion, P., Alesina, A., \& Trebbi, F. (2007, June). Democracy, technology, and growth (Working Paper No. 13180). National Bureau of Economic Research. Retrieved from http://www.nber.org/papers/w13180

Alesina, A., Ardagna, S., Nicoletti, G., \& Schiantarelli, F. (2005, June). Regulation and investment. Journal of the European Economic Association, 3(4), 791-825. Retrieved from http://dx.doi.org/10.1162/ 1542476054430834 doi: $10.1162 / 1542476054430834$

Alexander, S. S. (1949, August). The effect of size of manufacturing corporation on the distribution of the rate of return. The Review of Economics and Statistics, 31(3), 229-235. Retrieved from http:// www.jstor.org/stable/1927749

Alfaro, L., Charlton, A., \& Kanczuk, F. (2008, June). Plant-size distribution and cross-country income differences (Working Paper No. 14060). National Bureau of Economic Research. Retrieved from http://www.nber.org/papers/w14060

Ardagna, S., \& Lusardi, A. (2008, May). Explaining international differences in entrepreneurship: The role of individual characteristics and regulatory constraints (Working Paper No. 14012). National Bureau of 
Economic Research. Retrieved from http://www.nber.org/papers/ w14012

Ardagna, S., \& Lusardi, A. (2009a, November). Heterogeneity in the effect of regulation on entrepreneurship and entry size (Working Paper No. 15510). National Bureau of Economic Research. Retrieved from http://www .nber.org/papers/w15510

Ardagna, S., \& Lusardi, A. (2009b, February). Where does regulation hurt? Evidence from new businesses across countries (Working Paper No. 14747). National Bureau of Economic Research. Retrieved from http://www . nber .org/papers/w14747

Axtell, R. L. (2001). Zipf distribution of U.S. firm sizes. Science, 293(5536), 1818-1820. Retrieved from http://dx.doi.org/10.1126/ science.1062081 doi: 10.1126/science.1062081

Babecký, J., \& Campos, N. F. (2011). Does reform work? An econometric survey of the reform-growth puzzle. Journal of Comparative Economics, 39(2), 140-158. Retrieved from http://www.sciencedirect .com/science/article/pii/S0147596710000715 doi: 10.1016/j.jce .2010 .11 .001

Bena, J., \& Jurajda, S. (2007, June). Which firms benefit more from financial development? (CERGE-EI Working Papers No. 330). The Center for Economic Research and Graduate Education - Economics Institute, Prague. Retrieved from http://iweb.cerge-ei.cz/pdf/wp/ Wp330.pdf

Bertrand, M., \& Kramarz, F. (2002). Does entry regulation hinder job creation? Evidence from the French retail industry. The Quarterly Journal of Economics, 117(4), 1369-1413. Retrieved from http://dx.doi.org/10.1162/003355302320935052 doi: 10.1162/ 003355302320935052 
Botero, J. C., Djankov, S., La Porta, R., Lopez-de-Silanes, F., \& Shleifer, A. (2004). The regulation of labor. The Quarterly Journal of Economics, 119(4), 1339-1382. Retrieved from http://dx.doi.org/10.1162/ 0033553042476215 doi: 10.1162/0033553042476215

Bourlès, R., Cette, G., Lopez, J., Mairesse, J., \& Nicoletti, G. (2010, November). Do product market regulations in upstream sectors curb productivity growth? Panel data evidence for OECD countries (Working Paper No. 16520). National Bureau of Economic Research. Retrieved from http://www .nber .org/papers/w16520

Cabral, L. M., \& Mata, J. (2003, September). On the evolution of the firm size distribution: Facts and theory. American Economic Review, 93(4), 1075-1090. Retrieved from http://dx.doi.org/10.1257/ 000282803769206205 doi: 10.1257/000282803769206205

Cameron, A. C., \& Trivedi, P. K. (2005). Microeconometrics: Methods and applications. Cambridge University Press.

Commander, S., \& Nikoloski, Z. (2010, October). Institutions and economic performance: What can be explained? (IZA Discussion Papers No. 5247). Institute for the Study of Labor (IZA). Retrieved from http://ftp.iza.org/dp5247.pdf

Commander, S., \& Svejnar, J. (2011, February). Business environment, exports, ownership, and firm performance. The Review of Economics and Statistics, 93(1), 309-337. Retrieved from http://dx.doi.org/ 10.1162/REST_a_00135

Djankov, S., La Porta, R., Lopez-de-Silanes, F., \& Shleifer, A. (2002). The regulation of entry. The Quarterly Journal of Economics, 117(1), 1-37. Retrieved from http://dx.doi.org/10.1162/003355302753399436

Doi, N., \& Cowling, M. (1998). The evolution of firm size and employment share distribution in Japanese and UK manufacturing: A study 
of small business presence. Small Business Economics, 10, 283-292. Retrieved from http://dx.doi.org/10.1023/A\%3A1007903921724 doi: $10.1023 / \mathrm{A}: 1007903921724$

Dunne, T., Roberts, M. J., \& Samuelson, L. (1989, November). The growth and failure of U.S. manufacturing plants. The Quarterly Journal of Economics, 104(4), 671-698. Retrieved from http://www.jstor.org/ stable/2937862

Erzan, R., \& Filiztekin, A. (1997, April). Competitiveness of Turkish SMSEs in the customs union. European Economic Review, 41(3-5), 881-892. Retrieved from http://dx.doi.org/10.1016/S0014-2921(97)00045 $-7$

Franks, J. R., Schaefer, S. M., \& Staunton, M. D. (1997, December). The direct and compliance costs of financial regulation. Journal of Banking $\&$ Finance, 21(11-12), 1547-1572. Retrieved from http://dx.doi.org/ 10.1016/S0378-4266 (97)00045-9 doi: 10.1016/S0378-4266(97)00045 $-9$

Gabaix, X. (2009, August). The granular origins of aggregate fluctuations (Working Paper No. 15286). National Bureau of Economic Research. Retrieved from http://www.nber.org/papers/w15286

Gwartney, J., Hall, J., \& Lawson, R. (2012). 2012 economic freedom dataset. Economic Freedom of the World: 2012 Annual Report. Retrieved from http://www.freetheworld.com/release.html

Hashemi, F. (2000). An evolutionary model of the size distribution of firms. Journal of Evolutionary Economics, 10, 507-521. Retrieved from http://dx.doi.org/10.1007/s001910000048 doi: 10.1007/ s001910000048

Hashemi, F. (2003). A dynamic model of size distribution of firms applied to U.S. biotechnology and trucking industries. Small Business 
Economics, 21, 27-36. Retrieved from http://dx.doi.org/10.1023/ A\%3A1024433203253 doi: 10.1023/A:1024433203253

Henly, S. E., \& Sánchez, J. M. (2009). The U.S. establishment-size distribution: Secular changes and sectoral decomposition. Economic Quarterly, 95(4), 419-454. Retrieved from http://www.richmondfed.org/ publications/research/economic_quarterly/2009/fall/

Jovanovic, B. (1982, May). Selection and the evolution of industry. Econometrica, 50(3), 649-670. Retrieved from http://www.jstor.org/ stable/1912606

Kaizoji, T., Iyetomi, H., \& Ikeda, Y. (2005, December). Re-examination of the size distribution of firms (Quantitative Finance Papers No. physics/0512124). arXiv.org. Retrieved from http://ideas.repec . org/p/arx/papers/physics-0512124.html

Kaufmann, D., Kraay, A., \& Mastruzzi, M. (2010, September). The worldwide governance indicators: Methodology and analytical issues (Working Paper No. 5430). World Bank. Retrieved from http:// info. worldbank.org/governance/wgi/resources.htm

Klapper, L., Laeven, L., \& Rajan, R. (2006). Entry regulation as a barrier to entrepreneurship. Journal of Financial Economics, 82(3), 591-629. Retrieved from http://dx.doi.org/10.1016/j.jfineco.2005.09.006 doi: 10.1016/j.jfineco.2005.09.006

Lotti, F., \& Santarelli, E. (2004, January). Industry dynamics and the distribution of firm sizes: A nonparametric approach. Southern Economic Journal, $70(3)$, 443-466. Retrieved from http://www.jstor.org/ stable/4135325

Lucas, R. E. (1978, Autumn). On the size distribution of business firms. Bell Journal of Economics, 9(2), 508-523. Retrieved from http:// wwW. jstor.org/stable/3003596 
Mansfield, E. (1962, December). Entry, Gibrat's law, innovation, and the growth of firms. The American Economic Review, 52(5), 1023-1051. Retrieved from http://www.jstor.org/stable/1812180

Marsili, O. (2005, December). Technology and the size distribution of firms: Evidence from Dutch manufacturing. Review of Industrial Organization, 27, 303-328. Retrieved from http://dx.doi.org/10.1007/ s11151-005-5053-z doi: 10.1007/s11151-005-5053-z

Mata, J. (1994). Firm growth during infancy. Small Business Economics, 6, 27-39. Retrieved from http://dx.doi.org/10.1007/BF01066110 doi: $10.1007 / \mathrm{BF} 01066110$

Miller, T., Holmes, K. R., \& Feulner, E. J. (2013). 2013 index of economic freedom. Retrieved from http://www.heritage.org/index/ download

Millimet, D. L. (2003, July). Environmental abatement costs and establishment size. Contemporary Economic Policy, 21(3), 281-296. Retrieved from http://dx.doi.org/10.1093/cep/byg011 doi: 10.1093/cep/ byg011

Murphy, K. M., Shleifer, A., \& Vishny, R. W. (1991, May). The allocation of talent: Implications for growth. The Quarterly Journal of Economics, 106(2), 503-30. Retrieved from http://www.jstor.org/ stable/2937945

Rossi-Hansberg, E., \& Wright, M. L. J. (2007, December). Establishment size dynamics in the aggregate economy. American Economic Review, 97(5), 1639-1666. Retrieved from http://dx.doi.org/10.1257/aer .97.5.1639 doi: 10.1257/aer.97.5.1639

Samuels, J. M., \& Smyth, D. J. (1968, May). Profits, variability of profits and firm size. Economica, New Series, 35(138), 127-139. Retrieved from http://www.jstor.org/stable/2552126 
Stigler, G. J. (1988). Memoirs of an unregulated economist. New York: Basic Books.

Sutton, J. (1997, March). Gibrat's legacy. Journal of Economic Literature, 35(1), 40-59. Retrieved from http://www.jstor.org/stable/ 2729692

Sutton, J. (2007). Market structure: Theory and evidence. In M. Armstrong \& R. Porter (Eds.), Handbook of industrial organization (Vol. 3, p. 2301-2368). Elsevier. Retrieved from http://dx.doi.org/10.1016/ S1573-448X (06) 03035-4 doi: 10.1016/S1573-448X(06)03035-4

Winston, C. (1993, September). Economic deregulation: Days of reckoning for microeconomists. Journal of Economic Literature, 31 (3), 1263-89. Retrieved from http://www.jstor.org/stable/2728241 


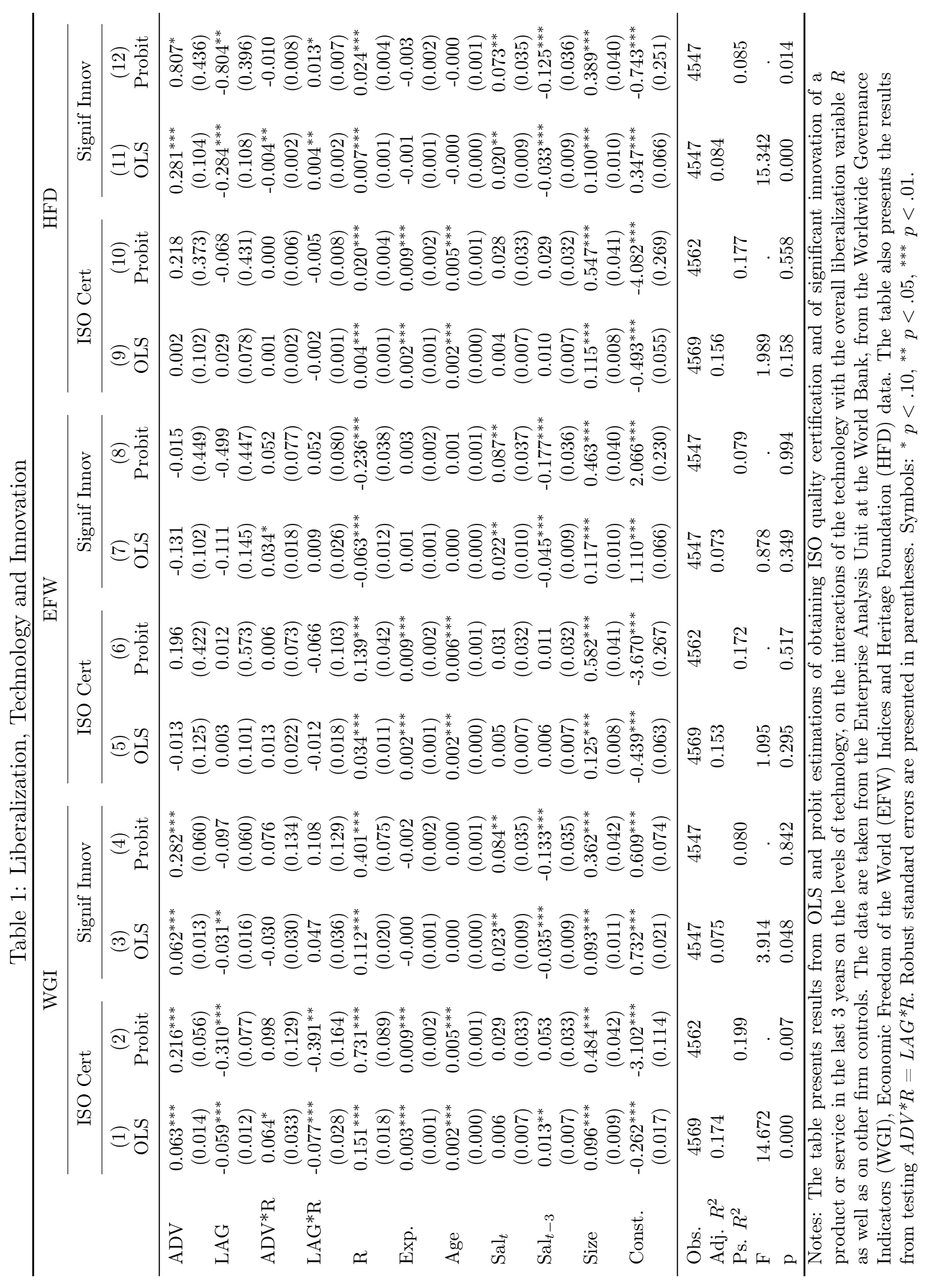


Table 2: Reforms and $\log (\mathrm{SPW})$ across Firms of Different Size

\begin{tabular}{|c|c|c|c|c|c|c|c|c|}
\hline & \multicolumn{4}{|c|}{ Size: $\log$ (No. of employees) } & \multicolumn{4}{|c|}{ Size: $\log$ (Value of assets) } \\
\hline & $(1)$ & $(2)$ & $(3)$ & $(4)$ & $(5)$ & (6) & $(7)$ & (8) \\
\hline & OLS & 2SLS & OLS & 2SLS & OLS & 2SLS & OLS & 2SLS \\
\hline \multirow[t]{2}{*}{$\log (\mathrm{SPW})_{t-1}$} & $.71^{* * *}$ & $.98^{* * *}$ & $.62^{* * *}$ & $.38^{* *}$ & $.71^{* * *}$ & .04 & $.62^{* * *}$ & $.78^{* * *}$ \\
\hline & $(.01)$ & $(.06)$ & $(.01)$ & $(.18)$ & $(.01)$ & $(.11)$ & $(.01)$ & $(.10)$ \\
\hline \multirow[t]{2}{*}{$\log (K P W)$} & $.15^{* * *}$ & .01 & $.11^{* * *}$ & $.19^{* * *}$ & $.11^{* * *}$ & $.41^{* * *}$ & $.09^{* * *}$ & $.18^{* * *}$ \\
\hline & $(.01)$ & $(.03)$ & $(.01)$ & $(.05)$ & $(.01)$ & $(.05)$ & $(.01)$ & $(.04)$ \\
\hline \multirow[t]{2}{*}{ CMR*Size } & $.00^{*}$ & .00 & .01 & .02 & -.00 & .01 & .00 & $.05^{* * *}$ \\
\hline & $(.00)$ & $(.01)$ & $(.01)$ & $(.02)$ & $(.00)$ & $(.01)$ & $(.00)$ & $(.01)$ \\
\hline \multirow[t]{2}{*}{$\mathrm{R}^{*}$ Size } & -.01 & -.01 & -.01 & -.01 & -.00 & $-.02^{*}$ & $-.02^{* *}$ & $-.11^{* * *}$ \\
\hline & $(.01)$ & $(.01)$ & $(.01)$ & $(.03)$ & $(.00)$ & $(.01)$ & $(.01)$ & $(.02)$ \\
\hline \multirow[t]{2}{*}{ RoL*Size } & $.02^{* * *}$ & .01 & $-.01^{*}$ & -.01 & $.01^{* * *}$ & $.02^{* * *}$ & $.01^{* *}$ & $.02^{* * *}$ \\
\hline & $(.00)$ & $(.01)$ & $(.01)$ & $(.02)$ & $(.00)$ & $(.00)$ & $(.00)$ & $(.01)$ \\
\hline \multirow[t]{2}{*}{$\mathrm{T}^{*}$ Size } & $-.01^{* * *}$ & $.01^{*}$ & $.01^{* *}$ & .00 & -.00 & $.02^{* * *}$ & $.01^{* * *}$ & $.02^{* * *}$ \\
\hline & $(.00)$ & $(.00)$ & $(.01)$ & $(.02)$ & $(.00)$ & $(.00)$ & $(.00)$ & $(.01)$ \\
\hline \multirow[t]{2}{*}{ Mgr. Exp. } & .00 & -.00 & -.00 & -.00 & .00 & .00 & -.00 & .00 \\
\hline & $(.00)$ & $(.00)$ & $(.00)$ & $(.00)$ & $(.00)$ & $(.00)$ & $(.00)$ & $(.00)$ \\
\hline \multirow[t]{2}{*}{ Firm Age } & .00 & -.00 & .00 & -.00 & .00 & -.00 & .00 & -.00 \\
\hline & $(.00)$ & $(.00)$ & $(.00)$ & $(.00)$ & $(.00)$ & $(.00)$ & $(.00)$ & $(.00)$ \\
\hline \multirow[t]{2}{*}{ Const. } & $.79^{* * *}$ & -.39 & $2.45^{* * *}$ & $4.27^{* * *}$ & $.85^{* * *}$ & $4.02^{* * *}$ & $2.47^{* * *}$ & $2.48^{* * *}$ \\
\hline & $(.11)$ & $(.39)$ & $(.13)$ & $(1.38)$ & $(.11)$ & $(.41)$ & $(.14)$ & $(.36)$ \\
\hline C'try Eff's & No & No & Yes & Yes & No & No & Yes & Yes \\
\hline Obs. & 16686 & 14383 & 16686 & 14383 & 16686 & 3133 & 16686 & 3133 \\
\hline Adj. $R^{2}$ & .825 & .795 & .845 & .832 & .826 & .679 & .845 & .839 \\
\hline Hansen J & & .02 & & .03 & & .55 & & .03 \\
\hline APF CMRS & & 110.9 & & 15.46 & & 451.1 & & 42.40 \\
\hline APF RS & & 68.59 & & 11.82 & & 162.5 & & 16.05 \\
\hline APF RLS & & 333.1 & & 47.77 & & 4158 & & 109.1 \\
\hline APF TS & & 399.8 & & 46.69 & & 342.3 & & 90.40 \\
\hline
\end{tabular}

Notes: The table presents results from OLS and 2SLS estimations of Log(Sales per worker) on lagged $\log (\mathrm{SPW}), \log ($ Capital per worker) and other observables from the firm-level data of the Enterprise Analysis Unit at the World Bank, and reform data, measured with Economic Freedom of the World (EFW) Indices, as well as on their interaction with firm size measured by either $\log$ (No. of employees) or $\log$ (Value of assets). All estimations include the age of the firm, its legal status, an indicator of a quality certificate and industryyear effects. Some estimations include country-year effects. The Hansen J-test and the first-stage Angrist-Pischke F-tests are given for each of the endogenous variables. Robust standard errors are in parentheses. Symbols: ${ }^{*} p<.10,{ }^{* *} p<.05,{ }^{* * *} p<.01$. 
Table 3: Reforms and Log(Sales) across Firms of Different Size

\begin{tabular}{|c|c|c|c|c|c|c|c|c|}
\hline & \multicolumn{4}{|c|}{ Size: $\log$ (No. of employees) } & \multicolumn{4}{|c|}{ Size: $\log ($ Value of assets) } \\
\hline & $(1)$ & $(2)$ & $(3)$ & $(4)$ & $(5)$ & (6) & $(7)$ & $(8)$ \\
\hline & OLS & 2SLS & OLS & 2SLS & OLS & 2SLS & OLS & 2SLS \\
\hline \multirow[t]{2}{*}{$\log (\mathrm{Sal})_{t-1}$} & $.60^{* * *}$ & $.89^{* * *}$ & $.59^{* * *}$ & $.50^{* *}$ & $.61^{* * *}$ & $.35^{* * *}$ & $.61^{* * *}$ & $.23^{* * *}$ \\
\hline & $(.01)$ & $(.31)$ & $(.01)$ & $(.25)$ & $(.01)$ & $(.07)$ & $(.01)$ & $(.09)$ \\
\hline \multirow[t]{2}{*}{$\log (\mathrm{K})$} & $.09^{* * *}$ & .01 & $.08^{* * *}$ & $.10^{*}$ & $.09^{* * *}$ & $.34^{* * *}$ & $.19^{* * *}$ & $.70^{* * *}$ \\
\hline & $(.01)$ & $(.08)$ & $(.01)$ & $(.05)$ & $(.01)$ & $(.07)$ & $(.03)$ & $(.16)$ \\
\hline \multirow[t]{2}{*}{$\log (\mathrm{L})$} & $.28^{* * *}$ & .14 & $.23^{* * *}$ & $.32^{* * *}$ & $.30^{* * *}$ & $.21^{* * *}$ & $.29^{* * *}$ & $.29^{* * *}$ \\
\hline & $(.01)$ & $(.19)$ & $(.01)$ & $(.11)$ & $(.01)$ & $(.03)$ & $(.01)$ & $(.04)$ \\
\hline \multirow[t]{2}{*}{ CMR*Size } & -.00 & -.00 & .00 & .01 & -.00 & .01 & -.00 & .02 \\
\hline & $(.00)$ & $(.02)$ & $(.01)$ & $(.02)$ & $(.00)$ & $(.00)$ & $(.00)$ & $(.02)$ \\
\hline \multirow[t]{2}{*}{$\mathrm{R}^{*}$ Size } & -.00 & .01 & -.01 & -.02 & .00 & -.02 & -.01 & -.04 \\
\hline & $(.00)$ & $(.03)$ & $(.01)$ & $(.03)$ & $(.00)$ & $(.01)$ & $(.01)$ & $(.03)$ \\
\hline \multirow[t]{2}{*}{ RoL.*Size } & $.02^{* * *}$ & .00 & -.00 & .01 & $.00^{* * *}$ & $.01^{* * *}$ & .00 & .02 \\
\hline & $(.00)$ & $(.01)$ & $(.00)$ & $(.02)$ & $(.00)$ & $(.00)$ & $(.00)$ & $(.01)$ \\
\hline \multirow[t]{2}{*}{$\mathrm{T}^{*}$ Size } & .00 & -.01 & $.03^{* * *}$ & .01 & $-.00^{* * *}$ & .01 & -.01 & $-.04^{*}$ \\
\hline & $(.00)$ & $(.01)$ & $(.01)$ & $(.01)$ & $(.00)$ & $(.01)$ & $(.00)$ & $(.02)$ \\
\hline \multirow[t]{2}{*}{ Mgr. Exp. } & .00 & -.00 & -.00 & -.00 & .00 & $.00^{* * *}$ & -.00 & $.00^{* *}$ \\
\hline & $(.00)$ & $(.00)$ & $(.00)$ & $(.00)$ & $(.00)$ & $(.00)$ & $(.00)$ & $(.00)$ \\
\hline \multirow[t]{2}{*}{ Firm Age } & $-.00^{* * *}$ & $-.00^{* * *}$ & $-.00^{* * *}$ & $-.00^{* *}$ & $-.00^{* * *}$ & $-.00^{*}$ & $-.00^{* * *}$ & -.00 \\
\hline & $(.00)$ & $(.00)$ & $(.00)$ & $(.00)$ & $(.00)$ & $(.00)$ & $(.00)$ & $(.00)$ \\
\hline \multirow[t]{2}{*}{ Const. } & $3.09^{* * *}$ & .00 & $1.16^{* * *}$ & 1.41 & $2.97^{* * *}$ & $1.68^{* * *}$ & $3.03^{* * *}$ & $1.88^{* * *}$ \\
\hline & $(.16)$ & $(.82)$ & $(.14)$ & $(1.12)$ & $(.16)$ & $(.22)$ & $(.20)$ & $(.25)$ \\
\hline C'try Eff's & No & No & Yes & Yes & No & No & Yes & Yes \\
\hline Obs. & 17207 & 13713 & 17207 & 13713 & 17207 & 3286 & 17207 & 3286 \\
\hline Adj. $R^{2}$ & .927 & .912 & .932 & .932 & .927 & .932 & .930 & .921 \\
\hline Hansen J & & .65 & & .04 & & .00 & & .46 \\
\hline APF CMRS & & 9.80 & & 25.16 & & 4512 & & 213.0 \\
\hline APF RS & & 8.32 & & 13.10 & & 1703 & & 84.76 \\
\hline APF RLS & & 536.8 & & 29.66 & & 32359 & & 577.4 \\
\hline APF TS & & 106.8 & & 53.60 & & 43461 & & 2166 \\
\hline
\end{tabular}

Notes: The table presents results from OLS and 2SLS estimations of Log(Sales) on lagged $\log (\mathrm{SAL}), \log$ (Capital), $\log$ (Labor costs) and other observables from the firm-level data of the Enterprise Analysis Unit at the World Bank, and on reform data, measured with Economic Freedom of the World (EFW) Indices, as well as on their interaction with the firm size measured by either $\log$ (No. of employees) or $\log$ (Value of assets). All estimations include the age of the firm, its legal status, an indicator of a quality certificate and industry-year effects. Some estimations include country-year effects. The Hansen J-test and the first-stage Angrist-Pischke F-tests are given for each of the endogenous variables. Robust standard errors are in parentheses. Symbols: ${ }^{*} p<.10,{ }^{* *} p<.05,{ }^{* * *}$ $p<.01$. 
Table 4: Reforms and $\Delta \log ($ SPW $)$ across Firms of Different Size

\begin{tabular}{|c|c|c|c|c|c|c|c|c|}
\hline & \multicolumn{4}{|c|}{ Size: $\log$ (No. of employees) } & \multicolumn{4}{|c|}{ Size: $\log$ (Value of assets) } \\
\hline & $(1)$ & $(2)$ & $(3)$ & $(4)$ & $(5)$ & $(6)$ & $(7)$ & (8) \\
\hline & OLS & 2SLS & OLS & 2SLS & OLS & 2SLS & OLS & 2SLS \\
\hline \multirow[t]{2}{*}{$\Delta \operatorname{LogKPW}$} & $.46^{* * *}$ & $.44^{* * *}$ & $.44^{* * *}$ & $.43^{* * *}$ & $.45^{* * *}$ & $.44^{* * *}$ & $.45^{* * *}$ & $.43^{* * *}$ \\
\hline & $(.04)$ & $(.04)$ & $(.04)$ & $(.04)$ & $(.04)$ & $(.05)$ & $(.04)$ & $(.05)$ \\
\hline \multirow[t]{2}{*}{$\mathrm{CMR}^{*}$ Size } & $.03^{* * *}$ & $.05^{* * *}$ & $.04^{* * *}$ & $.04^{* *}$ & $.01^{* * *}$ & $.02^{* * *}$ & $.02^{* * *}$ & $.05^{* * *}$ \\
\hline & $(.01)$ & $(.01)$ & $(.01)$ & $(.02)$ & $(.00)$ & $(.00)$ & $(.01)$ & $(.01)$ \\
\hline \multirow[t]{2}{*}{$\mathrm{R}^{*}$ Size } & $-.06^{* * *}$ & $-.08^{* * *}$ & $-.11^{* * *}$ & $-.09^{* * *}$ & $-.02^{* *}$ & $-.03^{* * *}$ & $-.06^{* * *}$ & $-.11^{* * *}$ \\
\hline & $(.02)$ & $(.02)$ & $(.02)$ & $(.03)$ & $(.01)$ & $(.01)$ & $(.02)$ & $(.02)$ \\
\hline \multirow[t]{2}{*}{ RoL*Size } & $.02^{* * *}$ & $.02^{* * *}$ & $.03^{* * *}$ & .02 & $.00^{* * *}$ & $.01^{* * *}$ & $.01^{* *}$ & $.02^{* *}$ \\
\hline & $(.00)$ & $(.00)$ & $(.01)$ & $(.01)$ & $(.00)$ & $(.00)$ & $(.01)$ & $(.01)$ \\
\hline \multirow[t]{2}{*}{$\mathrm{T}^{*}$ Size } & -.00 & .01 & $.02^{* * *}$ & $.03^{* * *}$ & -.00 & .00 & $.02^{* *}$ & $.02^{* * *}$ \\
\hline & $(.01)$ & $(.01)$ & $(.01)$ & $(.01)$ & $(.00)$ & $(.00)$ & $(.01)$ & $(.01)$ \\
\hline \multirow[t]{2}{*}{ Mgr. Exp. } & .00 & .00 & .00 & .00 & .00 & .00 & .00 & .00 \\
\hline & $(.00)$ & $(.00)$ & $(.00)$ & $(.00)$ & $(.00)$ & $(.00)$ & $(.00)$ & $(.00)$ \\
\hline \multirow[t]{2}{*}{ Firm Age } & $-.00^{*}$ & $-.00^{* * *}$ & $-.00^{*}$ & $-.00^{* * *}$ & -.00 & $-.00^{* *}$ & -.00 & $-.00^{* *}$ \\
\hline & $(.00)$ & $(.00)$ & $(.00)$ & $(.00)$ & $(.00)$ & $(.00)$ & $(.00)$ & $(.00)$ \\
\hline \multirow[t]{2}{*}{ Const. } & $.51^{* * *}$ & $.47^{* * *}$ & $.66^{* * *}$ & $.56^{* * *}$ & $.53^{* * *}$ & $.55^{* * *}$ & $1.13^{* * *}$ & $1.41^{* * *}$ \\
\hline & $(.14)$ & $(.15)$ & $(.15)$ & $(.16)$ & $(.17)$ & $(.17)$ & $(.26)$ & $(.28)$ \\
\hline C'try Eff's & No & No & Yes & Yes & No & No & Yes & Yes \\
\hline Obs. & 3840 & 3133 & 3840 & 3133 & 3840 & 3133 & 3840 & 3133 \\
\hline Adj. $R^{2}$ & .275 & .294 & .283 & .305 & .274 & .292 & .283 & .304 \\
\hline Hansen J & & .00 & & .00 & & .00 & & .00 \\
\hline APF CMRS & & 106.2 & & 49.77 & & 573.3 & & 63.05 \\
\hline $\mathrm{APF} \mathrm{RS}$ & & 32.84 & & 16.97 & & 217.3 & & 33.84 \\
\hline APF RLS & & 1637 & & 144.4 & & 9861 & & 178.0 \\
\hline APF TS & & 284.8 & & 104.3 & & 185.6 & & 268.2 \\
\hline
\end{tabular}

Notes: The table presents results from OLS and 2SLS estimations of the change in $\log$ (Sales per worker) on the change in $\log$ (Capital per worker) and other observables from the firm-level data of the Enterprise Analysis Unit at the World Bank and reform data, measured with Economic Freedom of the World (EFW) Indices, as well as on their interaction with the firm size measured by either $\log$ (No. of employees) or $\log$ (Value of assets). All estimations include the age of the firm, its legal status, an indicator of a quality certificate and industry-year effects. Some estimations include country-year effects. The Hansen J-test and the first-stage Angrist-Pischke F-tests are given for each of the endogenous variables. Robust standard errors are in parentheses. Symbols: ${ }^{*} p<.10$, ${ }^{* *} p<.05,{ }^{* * *} p<.01$. 
Table 5: Reforms and $\Delta \log ($ Sales $)$ across Firms of Different Size

\begin{tabular}{|c|c|c|c|c|c|c|c|c|}
\hline & \multicolumn{4}{|c|}{ Size: $\log$ (No. of employees) } & \multicolumn{4}{|c|}{ Size: $\log$ (Value of assets) } \\
\hline & $(1)$ & $(2)$ & $(3)$ & $(4)$ & $(5)$ & $(6)$ & $(7)$ & $(8)$ \\
\hline & OLS & 2SLS & OLS & 2SLS & OLS & 2SLS & OLS & 2SLS \\
\hline \multirow[t]{2}{*}{$\Delta \log (\mathrm{K})$} & $.36^{* * *}$ & $.37^{* * *}$ & $.34^{* * *}$ & $.35^{* * *}$ & $.35^{* * *}$ & $.36^{* * *}$ & $.34^{* * *}$ & $.35^{* * *}$ \\
\hline & $(.04)$ & $(.05)$ & $(.04)$ & $(.04)$ & $(.04)$ & $(.05)$ & $(.04)$ & $(.05)$ \\
\hline \multirow[t]{2}{*}{$\Delta \log (\mathrm{L})$} & $.30^{* * *}$ & $.31^{* * *}$ & $.31^{* * *}$ & $.32^{* * *}$ & $.31^{* * *}$ & $.32^{* * *}$ & $.32^{* * *}$ & $.33^{* * *}$ \\
\hline & $(.04)$ & $(.04)$ & $(.04)$ & $(.04)$ & $(.04)$ & $(.04)$ & $(.04)$ & $(.04)$ \\
\hline \multirow[t]{2}{*}{$\mathrm{CMR}^{*}$ Size } & $.04^{* * *}$ & $.05^{* * *}$ & $.05^{* * *}$ & $.04^{* *}$ & $.01^{* * *}$ & $.02^{* * *}$ & $.03^{* * *}$ & $.05^{* * *}$ \\
\hline & $(.01)$ & $(.01)$ & $(.01)$ & $(.02)$ & $(.00)$ & $(.00)$ & $(.01)$ & $(.01)$ \\
\hline \multirow[t]{2}{*}{$\mathrm{R}^{*}$ Size } & $-.06^{* * *}$ & $-.08^{* * *}$ & $-.12^{* * *}$ & $-.10^{* * *}$ & $-.02^{* *}$ & $-.03^{* * *}$ & $-.06^{* * *}$ & $-.11^{* * *}$ \\
\hline & $(.02)$ & $(.02)$ & $(.02)$ & $(.03)$ & $(.01)$ & $(.01)$ & $(.02)$ & $(.02)$ \\
\hline \multirow[t]{2}{*}{ RoL.*Size } & $.02^{* * *}$ & $.02^{* * *}$ & $.03^{* * *}$ & .02 & $.01^{* * *}$ & $.01^{* * *}$ & $.01^{* * *}$ & $.03^{* * *}$ \\
\hline & $(.00)$ & $(.00)$ & $(.01)$ & $(.01)$ & $(.00)$ & $(.00)$ & $(.00)$ & $(.01)$ \\
\hline \multirow[t]{2}{*}{$\mathrm{T}^{*}$ Size } & .00 & .01 & $.03^{* * *}$ & $.03^{* * *}$ & .00 & .00 & $.02^{* *}$ & $.02^{* * *}$ \\
\hline & $(.01)$ & $(.01)$ & $(.01)$ & $(.01)$ & $(.00)$ & $(.00)$ & $(.01)$ & $(.01)$ \\
\hline \multirow[t]{2}{*}{ Mgr. Exp. } & .00 & .00 & .00 & .00 & .00 & .00 & .00 & .00 \\
\hline & $(.00)$ & $(.00)$ & $(.00)$ & $(.00)$ & $(.00)$ & $(.00)$ & $(.00)$ & $(.00)$ \\
\hline \multirow[t]{2}{*}{ Firm Age } & $-.00^{* * *}$ & $-.00^{* * *}$ & $-.00^{* * *}$ & $-.00^{* * *}$ & $-.00^{* * *}$ & $-.00^{* * *}$ & $-.00^{* * *}$ & $-.00^{* * *}$ \\
\hline & $(.00)$ & $(.00)$ & $(.00)$ & $(.00)$ & $(.00)$ & $(.00)$ & $(.00)$ & $(.00)$ \\
\hline \multirow[t]{2}{*}{ Const. } & $.50^{* * *}$ & $.57^{* * *}$ & $.67^{* * *}$ & $.67^{* * *}$ & $.46^{* * *}$ & $.60^{* * *}$ & $1.08^{* * *}$ & $1.52^{* * *}$ \\
\hline & $(.14)$ & $(.14)$ & $(.15)$ & $(.16)$ & $(.16)$ & $(.17)$ & $(.25)$ & $(.28)$ \\
\hline C'try Eff's & No & No & Yes & Yes & No & No & Yes & Yes \\
\hline Obs. & 3840 & 3133 & 3840 & 3133 & 3840 & 3133 & 3840 & 3133 \\
\hline Adj. $R^{2}$ & .285 & .298 & .295 & .309 & .283 & .295 & .293 & .306 \\
\hline Hansen J & & .00 & & .00 & & .00 & & .00 \\
\hline APF CMRS & & 2585 & & 1029.4 & & 9110 & & 627.5 \\
\hline $\mathrm{APF} \mathrm{RS}$ & & 2603 & & 1155 & & 9884 & & 567.3 \\
\hline APF RLS & & 14492 & & 1673.4 & & 27712 & & 692.4 \\
\hline APF TS & & 94734 & & 58129 & & 167689 & & 28479 \\
\hline
\end{tabular}

Notes: The table presents results from OLS and 2SLS estimations of the change in $\log$ (Sales) on the change in $\log ($ Capital), the change in $\log$ (No. employess) and other observables from the firm-level data of the Enterprise Analysis Unit at the World Bank and on reform data, measured with Economic Freedom of the World (EFW) Indices, as well as on their interaction with the firm size measured by either Log(No. of employees) or $\log$ (Value of assets). All estimations include the age of the firm, its legal status, an indicator of a quality certificate and industry-year effects. Some estimations include country-year effects. The Hansen J-test and the first-stage Angrist-Pischke F-tests are given for each of the endogenous variables. Robust standard errors are in parentheses. Symbols: ${ }^{*} p<.10,{ }^{* *} p<.05,{ }^{* * *} p<.01$. 
Table 6: Reforms and $\log (\mathrm{SPW})$ across Firms of Different Size: Robustness

\begin{tabular}{|c|c|c|c|c|c|c|c|c|}
\hline & \multicolumn{4}{|c|}{ Size: $\log$ (No. of employees) } & \multicolumn{4}{|c|}{ Size: $\log$ (Value of assets) } \\
\hline & $\begin{array}{c}(1) \\
\text { OLS }\end{array}$ & $\begin{array}{c}(2) \\
\text { 2SLS }\end{array}$ & $\begin{array}{c}(3) \\
\text { OLS }\end{array}$ & $\begin{array}{c}(4) \\
2 \text { SLS } \\
\end{array}$ & $\begin{array}{c}(5) \\
\text { OLS }\end{array}$ & $\begin{array}{c}(6) \\
\text { 2SLS }\end{array}$ & $\begin{array}{c}(7) \\
\text { OLS }\end{array}$ & $\begin{array}{c}(8) \\
2 \text { SLS }\end{array}$ \\
\hline $\log (\mathrm{SPW})_{t-1}$ & $\begin{array}{l}.71^{* * *} \\
(.01)\end{array}$ & $\begin{array}{l}.96^{* * *} \\
(.03)\end{array}$ & $\begin{array}{l}.62^{* * *} \\
(.01)\end{array}$ & $\begin{array}{l}.66^{* * *} \\
(.13)\end{array}$ & $\begin{array}{l}.71^{* * *} \\
(.01)\end{array}$ & $\begin{array}{c}.04 \\
(.11)\end{array}$ & $\begin{array}{l}.62^{* * *} \\
(.01)\end{array}$ & $\begin{array}{l}.78^{* * *} \\
(.10)\end{array}$ \\
\hline $\log (\mathrm{KPW})$ & $\begin{array}{l}.15^{* * *} \\
(.01)\end{array}$ & $\begin{array}{c}.02 \\
(.02)\end{array}$ & $\begin{array}{l}.11^{* * * *} \\
(.01)\end{array}$ & $\begin{array}{l}.10^{* *} \\
(.04)\end{array}$ & $\begin{array}{l}.11^{* * *} \\
(.01)\end{array}$ & $\begin{array}{l}.41^{* * *} \\
(.05)\end{array}$ & $\begin{array}{l}.09^{* * * *} \\
(.01)\end{array}$ & $\begin{array}{l}.18^{* * *} \\
(.04)\end{array}$ \\
\hline $\mathrm{CMR}^{*}$ Size & $\begin{array}{l}.00^{*} \\
(.00)\end{array}$ & $\begin{array}{l}-.01 \\
(.01)\end{array}$ & $\begin{array}{c}.01 \\
(.01)\end{array}$ & $\begin{array}{c}.01 \\
(.02)\end{array}$ & $\begin{array}{l}-.00 \\
(.00)\end{array}$ & $\begin{array}{c}.01 \\
(.01)\end{array}$ & $\begin{array}{c}.00 \\
(.00)\end{array}$ & $\begin{array}{c}.05^{* * *} \\
(.01)\end{array}$ \\
\hline $\mathrm{R}^{*}$ Size & $\begin{array}{l}-.01 \\
(.01)\end{array}$ & $\begin{array}{c}.01 \\
(.01)\end{array}$ & $\begin{array}{l}-.01 \\
(.01)\end{array}$ & $\begin{array}{l}-.02 \\
(.03)\end{array}$ & $\begin{array}{l}-.00 \\
(.00)\end{array}$ & $\begin{array}{l}-.02^{*} \\
(.01)\end{array}$ & $\begin{array}{c}-.02^{* *} \\
(.01)\end{array}$ & $\begin{array}{c}-.11^{* * *} \\
(.02)\end{array}$ \\
\hline RoL*Size & $\begin{array}{l}.02^{* * *} \\
(.00)\end{array}$ & $\begin{array}{l}.01^{*} \\
(.00)\end{array}$ & $\begin{array}{l}-.01^{*} \\
(.01)\end{array}$ & $\begin{array}{l}-.01 \\
(.01)\end{array}$ & $\begin{array}{l}.01^{* * *} \\
(.00)\end{array}$ & $\begin{array}{l}.02^{* * *} \\
(.00)\end{array}$ & $\begin{array}{l}.01^{* *} \\
(.00)\end{array}$ & $\begin{array}{l}.02^{* * *} \\
(.01)\end{array}$ \\
\hline $\mathrm{T}^{*}$ Size & $\begin{array}{c}-.01^{* * *} \\
(.00)\end{array}$ & $\begin{array}{l}.01^{* *} \\
(.00)\end{array}$ & $\begin{array}{l}.01^{* *} \\
(.01)\end{array}$ & $\begin{array}{l}.02^{*} \\
(.01)\end{array}$ & $\begin{array}{l}-.00 \\
(.00)\end{array}$ & $\begin{array}{l}.02^{* * *} \\
(.00)\end{array}$ & $\begin{array}{l}.01^{* * *} \\
(.00)\end{array}$ & $\begin{array}{l}.02^{* * *} \\
(.01)\end{array}$ \\
\hline Mgr. Exp. & $\begin{array}{c}.00 \\
(.00)\end{array}$ & $\begin{array}{l}-.00 \\
(.00)\end{array}$ & $\begin{array}{l}-.00 \\
(.00)\end{array}$ & $\begin{array}{l}-.00 \\
(.00)\end{array}$ & $\begin{array}{c}.00 \\
(.00)\end{array}$ & $\begin{array}{c}.00 \\
(.00)\end{array}$ & $\begin{array}{l}-.00 \\
(.00)\end{array}$ & $\begin{array}{c}.00 \\
(.00)\end{array}$ \\
\hline Firm Age & $\begin{array}{c}.00 \\
(.00)\end{array}$ & $\begin{array}{l}-.00 \\
(.00)\end{array}$ & $\begin{array}{c}.00 \\
(.00)\end{array}$ & $\begin{array}{l}-.00 \\
(.00)\end{array}$ & $\begin{array}{c}.00 \\
(.00)\end{array}$ & $\begin{array}{l}-.00 \\
(.00)\end{array}$ & $\begin{array}{c}.00 \\
(.00)\end{array}$ & $\begin{array}{l}-.00 \\
(.00)\end{array}$ \\
\hline Const. & $\begin{array}{l}.79^{* * *} \\
(.11)\end{array}$ & $\begin{array}{l}-.27 \\
(.20)\end{array}$ & $\begin{array}{c}2.45^{* * *} \\
(.13)\end{array}$ & $\begin{array}{l}2.17^{* *} \\
(1.05)\end{array}$ & $\begin{array}{l}.85^{* * *} \\
(.11)\end{array}$ & $\begin{array}{c}4.02^{* * *} \\
(.41)\end{array}$ & $\begin{array}{c}2.47^{* * *} \\
(.14)\end{array}$ & $\begin{array}{c}2.48^{* * *} \\
(.36)\end{array}$ \\
\hline C'try Eff's & No & No & Yes & Yes & No & No & Yes & Yes \\
\hline Obs. & 16686 & 14383 & 16686 & 14383 & 16686 & 3133 & 16686 & 3133 \\
\hline Adj. $R^{2}$ & .825 & .800 & .845 & .851 & .826 & .679 & .845 & .839 \\
\hline Hansen J & & .00 & & .00 & & .55 & & .03 \\
\hline APF CMRS & & 104.0 & & 14.00 & & 451.1 & & 42.40 \\
\hline APF RS & & 59.84 & & 9.42 & & 162.5 & & 16.05 \\
\hline APF RLS & & 37.02 & & 56.75 & & 4158 & & 109.1 \\
\hline APF TS & & 391.3 & & 59.27 & & 342.3 & & 90.40 \\
\hline
\end{tabular}

Notes: The table presents results from OLS and 2SLS estimations of Log(Sales per worker) on lagged $\log (\mathrm{SPW}), \log ($ Capital per worker) and other observables from the firm-level data of the Enterprise Analysis Unit at the World Bank and reform data, measured with Economic Freedom of the World (EFW) Indices, as well as on their interaction with the firm size measured by either $\log$ (No. of employees) or $\log$ (Value of assets). All estimations include the age of the firm, its legal status, an indicator of a quality certificate and industry-year effects. Some estimations include country-year effects. The Hansen J-test and the first-stage Angrist-Pischke F-tests are given for each of the endogenous variables. Robust standard errors are in parentheses. Symbols: ${ }^{*} p<.10,{ }^{* *} p<.05,{ }^{* * *}$ $p<.01$. 
Table 7: Reforms and $\log (\mathrm{SPW})$ across Firms of Different Size: Robustness for CMR definition

\begin{tabular}{|c|c|c|c|c|c|c|c|c|}
\hline & \multicolumn{4}{|c|}{ Size: $\log$ (No. of employees) } & \multicolumn{4}{|c|}{ Size: $\log ($ Value of assets) } \\
\hline & $(1)$ & $(2)$ & $(3)$ & $(4)$ & $(5)$ & $(6)$ & $(7)$ & $(8)$ \\
\hline & OLS & 2SLS & OLS & 2SLS & OLS & 2SLS & OLS & 2SLS \\
\hline \multirow[t]{2}{*}{$\log (\mathrm{SPW})_{t-1}$} & $.68^{* * *}$ & $1.18^{* * *}$ & $.65^{* * *}$ & .36 & $.68^{* * *}$ & .05 & $.65^{* * *}$ & $.84^{* * *}$ \\
\hline & $(.02)$ & $(.06)$ & $(.02)$ & $(.33)$ & $(.02)$ & $(.12)$ & $(.02)$ & $(.10)$ \\
\hline \multirow[t]{2}{*}{$\log (\mathrm{KPW})$} & $.24^{* * *}$ & -.06 & $.19^{* * *}$ & $.32^{* *}$ & $.19^{* * *}$ & $.41^{* * *}$ & $.18^{* * *}$ & $.16^{* * *}$ \\
\hline & $(.02)$ & $(.04)$ & $(.01)$ & $(.15)$ & $(.02)$ & $(.06)$ & $(.02)$ & $(.04)$ \\
\hline \multirow[t]{2}{*}{ CMR*Size } & -.00 & $-.03^{* * *}$ & .00 & .00 & $-.00^{* * *}$ & .01 & -.00 & $.08^{* * *}$ \\
\hline & $(.00)$ & $(.01)$ & $(.01)$ & $(.02)$ & $(.00)$ & $(.01)$ & $(.01)$ & $(.02)$ \\
\hline \multirow[t]{2}{*}{$\mathrm{R}^{*}$ Size } & $.03^{* * *}$ & $.07^{* * *}$ & -.01 & $-.04^{*}$ & $.01^{* * *}$ & $-.02^{*}$ & .00 & $-.10^{* * *}$ \\
\hline & $(.00)$ & $(.01)$ & $(.01)$ & $(.02)$ & $(.00)$ & $(.01)$ & $(.01)$ & $(.02)$ \\
\hline \multirow[t]{2}{*}{ RoL*Size } & $.01^{* * *}$ & -.01 & .01 & .00 & $.00^{* * *}$ & $.02^{* * *}$ & .01 & .01 \\
\hline & $(.00)$ & $(.01)$ & $(.01)$ & $(.01)$ & $(.00)$ & $(.00)$ & $(.01)$ & $(.01)$ \\
\hline \multirow[t]{2}{*}{$\mathrm{T}^{*}$ Size } & $-.03^{* * *}$ & $-.01^{* * *}$ & .01 & $.04^{* * *}$ & $-.00^{* * *}$ & $.01^{* * *}$ & -.00 & -.01 \\
\hline & $(.00)$ & $(.00)$ & $(.01)$ & $(.01)$ & $(.00)$ & $(.00)$ & $(.01)$ & $(.01)$ \\
\hline \multirow[t]{2}{*}{ Mgr. Exp. } & $-.00^{* * *}$ & $-.00^{* *}$ & .00 & .00 & $-.00^{* *}$ & .00 & .00 & .00 \\
\hline & $(.00)$ & $(.00)$ & $(.00)$ & $(.00)$ & $(.00)$ & $(.00)$ & $(.00)$ & $(.00)$ \\
\hline \multirow[t]{2}{*}{ Firm Age } & $-.00^{* * *}$ & $-.00^{* *}$ & -.00 & $-.00^{*}$ & $-.00^{* * *}$ & -.00 & -.00 & -.00 \\
\hline & $(.00)$ & $(.00)$ & $(.00)$ & $(.00)$ & $(.00)$ & $(.00)$ & $(.00)$ & $(.00)$ \\
\hline \multirow[t]{2}{*}{ Const. } & .07 & $-1.78^{* * *}$ & $1.41^{* * *}$ & 2.96 & -.01 & $3.95^{* * *}$ & $1.57^{* * *}$ & $2.36^{* * *}$ \\
\hline & $(.12)$ & $(.32)$ & $(.18)$ & $(2.03)$ & $(.12)$ & $(.42)$ & $(.21)$ & $(.37)$ \\
\hline C'try Eff's & No & No & Yes & Yes & No & No & Yes & Yes \\
\hline Obs. & 5309 & 4600 & 5309 & 4600 & 5309 & 3069 & 5309 & 3069 \\
\hline Adj. $R^{2}$ & .893 & .828 & .901 & .886 & .894 & .687 & .901 & .830 \\
\hline Hansen J & & .00 & & .13 & & .28 & & .03 \\
\hline APF CMRS & & 687.7 & & 61.10 & & 239.6 & & 33.65 \\
\hline APF RS & & 394.3 & & 45.85 & & 209.1 & & 3.30 \\
\hline APF RLS & & 1248 & & 162.5 & & 4571 & & 229.6 \\
\hline APF TS & & 1144 & & 65.63 & & 551.7 & & 111.2 \\
\hline
\end{tabular}

Notes: The table presents results from OLS and 2SLS estimations of Log(Sales per worker) on lagged $\log (\mathrm{SPW}), \log ($ Capital per worker) and other observables from the firm-level data of the Enterprise Analysis Unit at the World Bank and reform data, measured with Economic Freedom of the World (EFW) Indices, as well as on their interaction with the firm size measured by either $\log$ (No. of employees) or $\log$ (Value of assets). All estimations include the age of the firm, its legal status, an indicator of a quality certificate and industry-year effects. Some estimations include country-year effects. The Hansen J-test and the first-stage Angrist-Pischke F-tests are given for each of the endogenous variables. Robust standard errors are in parentheses. Symbols: ${ }^{*} p<.10,{ }^{* *} p<.05,{ }^{* * *}$ $p<.01$. 


\section{Working Paper Series}

ISSN 1211-3298

Registration No. (Ministry of Culture): E 19443

Individual researchers, as well as the on-line and printed versions of the CERGE-EI Working Papers (including their dissemination) were supported from institutional support RVO 67985998 from Economics Institute of the ASCR, v. v. i.

Specific research support and/or other grants the researchers/publications benefited from are acknowledged at the beginning of the Paper.

(c) Petar Stankov, 2013

All rights reserved. No part of this publication may be reproduced, stored in a retrieval system or transmitted in any form or by any means, electronic, mechanical or photocopying, recording, or otherwise without the prior permission of the publisher.

Published by

Charles University in Prague, Center for Economic Research and Graduate Education (CERGE) and

Economics Institute of the ASCR, v. v. i. (EI)

CERGE-EI, Politických vězňů 7, 11121 Prague 1, tel.: +420 224005 153, Czech Republic.

Printed by CERGE-EI, Prague

Subscription: CERGE-EI homepage: http://www.cerge-ei.cz

Phone: + 420224005153

Email: office@cerge-ei.cz

Web: http://www.cerge-ei.cz

Editor: Michal Kejak

The paper is available online at http://www.cerge-ei.cz/publications/working_papers/.

ISBN 978-80-7343-289-8 (Univerzita Karlova. Centrum pro ekonomický výzkum a doktorské studium)

ISBN 978-80-7344-281-1 (Národohospodářský ústav AV ČR, v. v. i.) 
CERGE-EI

P.O.BOX 882

Politických vězňů 7

11121 Praha 1

Czech Republic http://www.cerge-ei.cz 